\title{
Editorial
}

\section{A Constitutional moment: Acceding to the ECHR (or not)}

The Court of Justice of the European Union has spoken: accession to the European Convention on Human Rights on the terms specified in the Draft Accession Agreement ${ }^{1}$ is incompatible with Union law as it stands and as established by the Court of Justice. $^{2}$

Few really expected this outcome - all the more since the Court had put its stamp on some essential elements in the negotiations, by an unprecedented and increasingly explicit institutional intervention in the lead-up to the draft accession agreement ${ }^{3}$ - or should that have been a warning?

And yet it is fully within the Court's powers to give a negative opinion. It is, however, not in the power of the Court to decide what to do next. So, the decision whether to accede to the ECHR is not for the Court to determine. This is ultimately for the member states to decide, either qua members of the Council as the EU treaty-making power, ${ }^{4}$ or qua member states as masters of the EU Treaties in the framework of the amendment procedure ${ }^{5}$ - this follows from Article 218 (11) TFEU (though the European Parliament and Commission will inevitably be involved in both instances).

Article 218(11) TFEU is quite clear on what the consequence is of the Court's negative opinion: the EU cannot accede to the ECHR, unless either the envisaged accession agreement or the EU Treaties are revised. ${ }^{6}$ This means that under

\footnotetext{
${ }^{1}$ Final Report to the CDDH, Strasbourg 10 June 2013, $47+1$ (2013)008rev2, <www.coe.int/t/ dlapil/cahdi/Source/Docs2013/47_1_2013_008rev2_EN.pdf>, visited 26 March 2015.

${ }^{2}$ ECJ 18 December 2014, Opinion 2/13.

${ }^{3}$ On this, L.F.M. Besselink, 'Should the European Union Ratify the European Convention for Human Rights: Some Remarks on the Relations between the European Court of Human Rights and the European Court of Justice', in A. Føllesdal et al. (eds.), Constituting Europe: the European Court of Human Rights in a national, European and global context (Cambridge University Press 2013) p. 301-333.

${ }^{4}$ Art. 218(2) TFEU.

${ }^{5}$ Art. 48(4) TEU.

${ }^{6}$ Art. 218(11) TFEU: 'A Member State, the European Parliament, the Council or the Commission may obtain the opinion of the Court of Justice as to whether an agreement envisaged is
} 
Article 218(11) TFEU three options are open: the option not to accede to the ECHR, the option to amend the Draft Accession Agreement, or the option to amend the EU Treaties.

Each of these three routes entails a constitutional amendment, as we explain presently. Not only in this sense do the choices open to the member states imply a formal 'constitutional moment'; each of these three amendments also has substantive consequences both for the Union's internal position on fundamental rights and for its position within the larger Europe and the larger world as regards human rights and rule of law accountability. ${ }^{7}$ Each of the options constitutionally affects the Union's position differently. It is a moment of constitutional choice.

One might think that the first option, i.e. to decide not to enter into the envisaged international agreement, is merely a matter of doing nothing. Usually, not to act is enough, but this is not true for accession to the ECHR. After all, Article 6(2) TEU imposes the obligation for the EU to accede. In this case, even a decision not to accede cannot unconditionally be made: it can only lawfully be taken in the form of - or after - an amendment revoking Article 6(2) TEU (and the attendant Protocol $\mathrm{nr}$ 8). Article 6(2) TEU is not expressing a mere expectation; it is a legal commitment on the part of the European Union to accede, which self-evidently binds both the EU institutions and the member states. As the provision does not contain a limitation in time, Article 6(2) TEU only allows the Union not to accede yet. ${ }^{8}$ But deciding not to accede to the ECHR at all requires an amendment of EU primary law. It might be possible that in the long run, desuetude might have a derogatory effect, but this requires actual practice, and it is hard to be sure how this could be established in this case.?

Removing the legal obligation for the EU and its member states to accede to the ECHR by eliding Article 6(2) TEU is technically an easy thing to do, assuming that the procedural requirements for the amendment can be fulfilled, among which unanimity among member states (and parliaments - and possibly even popular referenda - that need to approve the ratification of this Treaty amendment),

compatible with the Treaties. Where the opinion of the Court is adverse, the agreement envisaged may not enter into force unless it is amended or the Treaties are revised'.

${ }^{7}$ See the incisive remarks by J.-P. Jacqué, 'Non à l'adhésion à la Convention européenne des droits de l'homme?', <www.droit-union-europeenne.be/412337458>, visited 26 March 2015.

${ }^{8} \mathrm{We}$ can base this on the case law on the Treaty provision concerning the seat of the EP, e.g. ECJ, Case 230/81, Luxembourg v Parliament [1983] ECR 255, para. 35: '[Member States] not only have the competence but also the duty to exercise that competence'.

${ }^{9}$ See in general I. Buga, The Modification of Treaties by Subsequent Practice: The Implications of Practice Going Beyond the Limits of Treaty Interpretation (dissertation Utrecht 2015) <dspace.library. uu.nl/handle/1874/306041>, visited 26 March 2015; she points to the ECJ case law in Case 812/79, Burgoa [1980] ECR 2787, para. 24, and Case C-181/80, Arbelaiz-Emazabel [1981] ECR 2961, para. 30, (and the AG opinion in this case), but there are no clear analogies with the issue under Art. 6(2) TEU. 
and of course those of Article 48(3) TEU, none of which can be taken for granted at the moment. Abolishing Article 6(2) is normatively and constitutionally far-reaching, and is contrary to all the reasons why it was deemed desirable to make accession a legal duty, as was the choice of the Intergovernmental Conference that established the Treaty on a Constitution for Europe and was honoured in the IGC that negotiated the Lisbon Treaty. Article 6(2) was introduced after the Court of Justice had determined in Opinion 2/94 that accession of the (then) European Communities to the ECHR was in conflict with EU law. Accession, due to its far-reaching institutional implications for the EC and the member states, has 'a constitutional dimension' which requires an explicit basis in the Treaties, so the Court held. ${ }^{10}$ The Lisbon Treaty created the required constitutional basis, not by making accession a legally permissible option, but by imperatively providing that 'The Union shall accede...'. Protocol No. 8 relating to Article 6(2) TEU does indeed stipulate a number of conditions that accession has to live up to, but this does not diminish the primary obligation to accede. A choice to amend this away again requires a justification that outweighs the reasons for adopting 6(2) TEU.

The second option that Article 218(11) TFEU provides is that of re-negotiating the accession agreement in order to cater to the objections of the Court of Justice. Clearly, this would be a choice that respects the obligation to accede. There are some practical obstacles that would need to be overcome; and this is unlikely to happen in practice.

First of all, there is no guarantee that the member states will be able to agree on a negotiating mandate in the Council. This proved to be tough in the earlier rounds, and will be close to impossible to reach now. After all, France - which had objected to the first Draft Accession Agreement that was negotiated with the non-EU parties to the ECHR and the Council of Europe - will find it was proven right by the Court in demanding an exception to ECtHR jurisdiction as regards Common Foreign and Security Policy (CFSP). Although it went along with the revised, second Draft Accession Agreement that did not create such an exception it was evidently hard to justify for non-EU parties to the ECHR - it is likely to rekindle its old objection. Moreover, it is not unlikely that the UK will do exactly the same on its plethora of - mainly minor - objections, simply because the political mood in the UK requires it. Other member states, to the contrary, might not want to retract on the compromises reached.

Secondly, renegotiation requires the non-EU parties to the ECHR, as well, to return to the negotiating table. That would be for the third round of negotiations in total, and for the second time because the EU has internal problems with earlier agreed accession conditions. We only need to look at the declaration by Russia at

${ }^{10}$ ECJ 28 March 1996, Opinion 2/94, para. 35. 
the opening of the second round - basically stating that if the EU and its member states were to retract on earlier compromises, the Russian Federation could not be expected not to do so as well - to understand that the chances are slim that it will appear at the table at all, ${ }^{11}$ leaving aside that the geo-political conflicts rifting Europe apart will not make Russia a willing partner. One may also wonder whether the other earlier major objectors, Switzerland and Turkey, would suddenly be convinced, after reading the press release on Opinion $2 / 13$, that the Union really is something quite different from them as a party to the ECHR, and rush to the negotiating table on the basis of the deeper insights provided by the Court. Many of the points on which the Court of Justice seeks remedies would be ever-so-many further exceptions for the EU only, some weaker forms of which have understandably already given rise to principled objections among the nonEU parties to the ECHR. ${ }^{12}$

Thirdly, the outcome of the renegotiated, third, draft Accession Agreement could yet again be subjected to the scrutiny of the Court of Justice, which has shown an unusual degree of unpredictability, given its striking down of some of the provisions of the accession agreement it had itself insisted upon (notably the 'prior involvement procedure' that creates the privilege for the ECJ to adjudicate any claim made to Strasbourg of incompatibility of EU law with the Convention if the ECJ has not previously decided the validity of the relevant EU law.).

Article 218(11) TFEU explicitly mentions the third option open to the member states: that is the amendment of the EU Treaties. We must be clear and explicit on the intent of this option: its essence is that the EU Treaties are amended to remove the obstacles identified by the Court in a negative Opinion.

Thus, in the first of the Court's Opinions on accession to the ECHR (Opinion 2/94) the identified obstacle was the lack of a legal basis in the Treaties. This was solved in the Lisbon Treaty - in line with the abortive Constitutional Treaty - by

\footnotetext{
${ }^{11}$ See the Second Negotiation Meeting between the CDDH Ad Hoc Negotiation Group and the European Commission on the Accession of the European Union to the ECHR, Relevant excerpts from the report of the 75th meeting of the CDDH, Strasbourg 4 July 2012, $47+1(2012) 002$, Appendix VI, <www.coe.int/t/dghl/standardsetting/hrpolicy/accession/Working_documents/47_1 (2012)02_Extracts_CDDH_Report_EN.pdf $>$, visited 26 March 2015.

${ }^{12}$ See the Common Paper by the non-EU member state parties to the Convention (Andorra, Armenia, Azerbaijan, Bosnia-Herzegovina, Iceland, Liechtenstein, Monaco, Montenegro, Norway, Serbia, Switzerland, Russian Federation, Turkey and Ukraine, also 'NEUMS'), Strasbourg

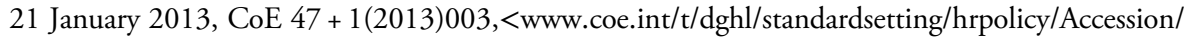
Working_documents/47_1(2013)003_EN.pdf>, visited 26 March 2015, concerning 'the principle of equal footing'. E.g. see point 13 on the procedure of 'prior involvement of the ECJ': 'The NEUMS affirm that the prior involvement of the Luxembourg Court is not consistent with the principle of subsidiarity, that the procedure would constitute a privilege for one Contracting Party and that the impact on the Strasbourg Court of the assessment made by the Luxembourg Court should not be underestimated'.
} 
introducing the duty to accede in Article 6(2) TEU. The Lisbon Treaty was thus making use of the third option under what is now Article 218(11) TFEU.

In the case of Opinion 2/13, the option of amending the Treaties must necessarily mean: taking away Treaty obstacles that stand in the way of accession.

This can be done in several manners. One of them is that of amendment so as to repair the specific points that stand in the way of accession; another is that of amendment of the EU treaties to express the will of the EU constituent power to have the EU accede to the ECHR notwithstanding Opinion 2/13.

If the first approach is taken, some of the points raised by the Court could be accommodated in a fairly straightforward manner. For instance the lack of ECJ competence with regard to the CFSP: this could be solved by removing this exception to the Court's jurisdiction in Article 24(1), last sentence, TEU (and related provisions).

For the objection that the ECHR undermines the principle of mutual recognition in the field of the Area of Freedom, Security and Justice, things are already more complicated. The relevant AFSJ instruments could either be amended so as to allow for a judicial review of compatibility with the ECHR in concrete cases: a possibility already recognised in some of the civil law instruments, but paradoxically generally absent in the criminal law instruments, most controversially in the EAW Framework Decision. This would in part codify ECJ case law, ${ }^{13}$ and in part the standing ECtHR case law, ${ }^{14}$ and in its combination and extension to all AFSJ instruments take away this obstacle identified in Opinion 2/13, at least if we were to understand the wording of Article 218(11) TFEU so broadly as to allow amendment of secondary EU law as a sufficient solution. Perhaps it is not a sufficient solution. The suggested amendment of secondary law may be understood as a legislative interpretation of primary law, or alternatively as not being prohibited by primary law while practically removing the point identified by the Court in its Opinion. Even so, Article 218(11) TFEU speaks of revision of 'the Treaties' and we may have to take this to mean that in

\footnotetext{
${ }^{13}$ E.g. ECJ 21 December 2011, Joint cases C-411/10 and C-493/10, N.S. and ECJ 30 May 2013, Case C-168/13 PPU, Jeremy F. v Premier ministre, as well as the suggestion made in opinions such as those of AG Sharpston in Case C-396/11, Radu, points $71 \mathrm{ff}$.; AG Cruz Villalón in Case C-306/09, I.B. [2010] ECR I-10341, paras. 43-44; AG Bot in Case C-123/08, Wolzenburg [2009] ECR I 9621, points 148 and 151; AG Mengozzi in Case C 42/11, Lopes da Silva Jorge, point 28.

${ }^{14}$ Notably case law in the field of Art. 3 ECHR such as ECtHR 21 January 2011, no. 30696/09, M.S.S. v Belgium and Greece (Grand Chamber), which was basically accepted by the ECJ in N.S., n. 13 supra, and more recently the case law on Article 8 ECHR such as ECtHR 4 November 2014, no. 29217/12, Tarakhel v Switzerland (Grand Chamber) and in the child abduction cases, e.g. ECtHR 12 July 2011, no. 14737/09, Šneersone and Kampanella v Italy (Second Section), relying essentially on ECtHR 6 July 2010, no. 41615/07, Neulinger and Shuruk v Switzerland (Grand Chamber).
} 
case of a negative opinion, only primary EU law can legitimately undo the Court's negative opinion. ${ }^{15}$ Still, the Treaties could resolve the issue by explicitly allowing for a human rights reservation: this could, for instance, be done by adding after the words 'the mutual recognition of judgments in criminal matters'/ 'mutual recognition of judicial and extrajudicial decisions in civil matters' in Articles 67(3) and (4) the clause: ' $\ldots$ unless such recognition is contrary to fundamental rights under Article 6 TEU' - but other formulations could be thought of (and that could lead to quite a few points that would require negotiation). ${ }^{16}$

In theory, such amendments are feasible. It is much more difficult, however, to remove the deeper cause for the Court's conclusion on the issues on which it finds accession to be incompatible with EU law: the 'very nature of EU law' and 'the constitutional structure of the EU', in particular the 'autonomy of the Union' and its institutions, of which most importantly that of the Court itself. It would be unwise to remove this obstacle in the form of a general denial of the Union's 'autonomy'. True to the spirit of European integration, it would nevertheless be appropriate to do with 'autonomy' what the Court of Justice did to 'sovereignty' in Van Gend \& Loos in order to make the Union safe from solipsism. The Court made 'sovereignty' harmless by refracting it into 'sovereign rights' ${ }^{17}$ or 'sovereign powers ${ }^{18}$ and spoke of 'restricting' them 'albeit in limited fields' to the advantage of European institutions endowed with 'sovereign rights' or 'sovereign powers. ${ }^{19}$ For the Union's 'autonomy' in the context of integration into the larger Europe, the Van Gend \& Loos approach would mean that the Union restricts its autonomous powers, albeit in the limited field of fundamental rights protection under the ECHR and its supervisory mechanisms.

Such a variation on the theme of Van Gend \& Loos might be an excellent opening to the preamble of an instrument that takes the second approach mentioned above, and sets aside all the obstacles in a single, legally watertight instrument that solves all issues in one go: a 'notwithstanding protocol', to be adopted under Article $48 \mathrm{TEU}$, that in essence declares that the Union accedes to

\footnotetext{
${ }^{15}$ Similarly, one may wonder whether the removal of some obstacles by making a set of unilateral declarations by the Union and by the member states, some of which similar to 'disconnection clauses' that have been adopted in other Council of Europe conventions, as suggested by Pieter Jan Kuijper, amount to a revision of the Treaties in the sense of Art. 218(11) TFEU.

${ }^{16}$ For instance, a wording which replaces 'is contrary' with 'is manifestly contrary' might be closer to what Advocates General have advocated, for instance, with regard to Art. 6 ECHR. This would still leave it up to the Court of Justice and the ECtHR to determine and adapt the intensity of judicial scrutiny depending on the rights involved and the particular circumstances of the case.

${ }^{17}$ In the French and German (and later in the English) language versions.

${ }^{18}$ In the Italian language version ('poteri sovrani').

${ }^{19}$ Except in the Dutch language version, which unlike the other original language versions speaks of sovereignty ('soevereiniteit') tout court.
} 
the ECHR on the basis of the Agreement on the accession of the European Union to the Convention for the Protection of Human Rights and Fundamental Freedoms of 5 April 2013 and Article 218 TFEU, notwithstanding the provisions of the Treaties as interpreted in Opinion 2/13 of the Court of Justice. ${ }^{20}$ Adopting this Protocol amends the Treaties by exempting the application of the ECHR from conflicting EU primary law that would otherwise stand in the way of accession. This way of proceeding obviates the need to go through all varieties of possible solutions to the large list of problems thrown up in Opinion 2/13, and its attending uncertainties - one of which is even how many the Court has identified. ${ }^{21}$ Instead of getting lost in the thicket of member state disagreements on each of the various topics, all of which run the risk of derailing the process, it clears the road to accession by placing the political objective that the Union is set to attain centre stage.

Such a solution takes inspiration from member states' constitutional clauses and practices that were used and designed to overcome possible constitutional obstacles to further European integration. Thus there are clauses that explicitly allow becoming a party to EU Treaties that deviate from the respective constitutions. The Portuguese Constitution allows the application of formal or substantive unconstitutional EU law. ${ }^{22}$ Finland is another example of a country where exceptive enactments can be used to overcome constitutional hurdles, which indeed were used to make accession to the EU possible. ${ }^{23}$ The Dutch constitution also has a broadly formulated provision with similar effect. In practice this type of provision results in a substantive change of the constitution without a textual amendment of specific provisions with a view to further European

\footnotetext{
${ }^{20}$ See <acelg.blogactiv.eu/2014/12/24/acceding-to-the-echr-notwithstanding-the-court-of-justiceopinion-213/\#more-469>, and <www.verfassungsblog.de/acceding-echr-notwithstanding-court-justiceopinion-213/>, both visited 26 March 2015. In due course, the reference to the Accession Agreement must be adapted. Textual variants to the same effect as here proposed are imaginable.

${ }^{21}$ The Council's Legal Service in an 'information note' comes to 'ten issues', Council 14 January 2015, 5227/15, p. 5; Pieter Jan Kuijper comes to seven obstacles under six headings that need to be removed, http://acelg.blogactiv.eu/2015/01/06/reaction-to-leonard-besselinks's-acelg-blog/, visited 26 March 2015

${ }^{22}$ Art. 277(2) Portuguese Constitution, which does, however, make an exception for breaches of a 'fundamental' provision of the Constitution. The counterpart of this is Article 279(2) Portuguese Constitution which allows for becoming a party to a treaty that has been declared unconstitutional by the Tribunal Constitucional if the Assembly of the Republic approves the treaty with a majority of two thirds of the votes cast, constituting a majority of the members of the Assembly (normally treaties can be approved by simple majority of the votes cast; constitutional amendment is by two thirds of the members). The procedure under Article 279(2) Portuguese Constitution has not been used so far.

${ }^{23}$ This instrument was also used to make ratification of the Amsterdam Treaty possible and also to implement the European Arrest Warrant Framework Decision.
} 
integration. Other member states' constitutional practices in case of an EU Treaty amendment that was found to be incompatible with national primary law go in the same direction. Think of the amendment of the French Constitution, adopted after the Conseil constitutionnel declared the Lisbon Treaty incompatible with the Constitution on a number of points, to specify that France can participate in the Union on the basis of the provisions of the Treaties. ${ }^{24}$ The Irish method of adopting a constitutional amendment incorporating the EU Treaties has comparable effects, ${ }^{25}$ while Germany and other member states made constitutional amendments to constitutionally cater for further European integration as well. In practice, each time when a national constitutional provision stood in the way of further integration due to amendment of the Union Treaties, member states have removed the constitutional obstacle by constitutional amendment. Now that the integration of the Union itself into the larger Europe of fundamental rights is at stake and EU constitutional obstacles have been identified, the Union could follow the path shown by the member states.

The solution of acceding on the basis of a 'notwithstanding protocol' is entirely loyal to the spirit of European integration, which has always extended beyond the confines of the existent Communities or the Union. European integration has always had a twofold foundation: on the one hand the Communities and Union and on the other hand the larger Europe of the Council of Europe. ${ }^{26}$ The former have always been conceived of as being rooted in the political values of democracy, the latter in the rule of law and fundamental rights. This has involved the

${ }^{24}$ Loi constitutionnelle n ${ }^{\circ} 2008-103$ du 4 février 2008, Art. 1 amending Art. 88-1 Constitution to read '[La République] peut participer à l'Union européenne dans les conditions prévues par le traité de Lisbonne modifiant le traité sur l'Union européenne et le traité instituant la Communauté européenne, signé le 13 décembre 2007'.

${ }^{25}$ Constitution of Ireland, Art. 29(4) $5^{\circ}$ : 'The State may ratify the Treaty of Lisbon amending the Treaty on European Union and the Treaty establishing the European Community, signed at Lisbon on the 13th day of December 2007 ("Treaty of Lisbon"), and may be a member of the European Union established by virtue of that Treaty'. Art. 29(4) 6': 'No provision of this Constitution invalidates laws enacted, acts done or measures adopted by the State, before, on or after the entry into force of the Treaty of Lisbon, that are necessitated by the obligations of membership of the European Union referred to in subsection $5^{\circ}$ of this section or of the European Atomic Energy Community, or prevents laws enacted, acts done or measures adopted by [the EU and its institutions and bodies] from having the force of law in the State'. Art. 29(10): The State may ratify the Treaty on Stability, Coordination and Governance in the Economic and Monetary Union done at Brussels on the 2nd day of March 2012. No provision of this Constitution invalidates laws enacted, acts done or measures adopted by the State that are necessitated by the obligations of the State under that Treaty or prevents laws enacted, acts done or measures adopted by bodies competent under that Treaty from having the force of law in the State'.

${ }^{26} \mathrm{Cf}$. Eric Stein's claim that the European Communities and the ECHR form 'the two faces' of the 'emerging European Constitution', 'The Emerging European Constitution', Proceedings of the Annual Meeting of the American Society of International Law, Vol. 72 (1978) p. 168. 
subjection of states to the Council of Europe's core instrument, the European Convention on Human Rights, and submitting them to the supervisory mechanisms of that Convention, including the European Court of Human Rights. It was not enough for the legal and political orders to proclaim themselves committed to the values of human rights protection in their own constitutional documents. It required more than 'self-binding' constitutionalism. It required an 'external', legally binding commitment towards all like-minded political orders in Europe to submit to the ECHR and its institutions, thus providing for a truly European anchor for democratic orders under the rule of law. This is what is at stake when the question of the Union's accession is raised: the Union's commitment to the political values underlying European integration.

It is this consideration that renders unfounded the allegations that a 'notwithstanding protocol' is a form of 'disobedience' to the Court, of undermining its authority further than it has itself already done in Opinion 2/13, and even of such a protocol being in conflict with the duty of loyal cooperation. To the contrary, suggesting that the member states have to carry out the Court's opinion and must go back to the negotiating table to redraft the terms of the accession to do so, is simply contrary to the clear wording of Article 218(11) TFEU. It would be vesting the Court with a constitution-making power that is clearly at variance with the Treaties. ${ }^{27}$ To prevent such a situation, any constitutional system allows for the possibility to overcome a judicial declaration of unconstitutionality if the proper procedure is followed, and the EU is no exception. ${ }^{28}$

Politically, accession on the basis of a 'notwithstanding protocol' would be feasible if and as long as the member states are sincerely committed to fulfilling their obligations under Article 6(2) TEU to accede - a legitimate premise as long as this provision exists. It is also fully consistent with the legal views expressed in the proceedings at the Court of Justice by all member states, European Parliament, Commission and Council that the present draft Accession Agreement is compatible with EU law. ${ }^{29}$ Of course, this commitment can also be fulfilled by following the more arduous route of amending EU law on the five, seven or ten points raised by the Court. And also a 'notwithstanding protocol' would not

${ }^{27}$ The only (procedural) oversight of the Court applies to the simplified amendment procedure; see ECJ 27 November 2012, Case C-370/12, Pringle, paras. 30-37.

${ }^{28}$ That this also applies to the member states' constitutions that contain 'eternity clauses', is shown in L.F.M. Besselink et al., National Constitutional Avenues for Further EU Integration (European Parliament 2014), PE 493.046 EN, <www.europarl.europa.eu/RegData/etudes/etudes/ join/2014/493046/IPOL-JURI_ET(2014)493046_EN.pdf>, visited 26 March 2015.

${ }^{29}$ Cf. ECJ 18 December 2014, Opinion 2/13, paras. 108-109. The only member states that did not intervene at the Court were Croatia, Slovenia, Luxembourg and Malta. None of them have ever expressed the view that accession on the terms of the draft Accession Agreement is incompatible with EU law. 
obviate the necessity of 'internal rules' connected with the accession, some of which touch upon issues raised in Opinion 2/13.

A totally different issue is how likely it is that any of the above routes will be followed.

The state of play as far as any outsiders know at the moment of writing, two months after the Opinion was handed down, is that no member state nor institution has taken a public position either on it, or on what to do next. ${ }^{30}$ In fact, the questions to answer are difficult and no doubt controversial. Do the member states and institutions really want to accede to the ECHR, and if so, would they want to do so on the terms deriving from Opinion 2/13? Is the cause of protecting citizens against Union action served by the severe restrictions that the Court finds desirable in light of what it considers to be the 'very nature of Union law'? Do we want to have a Union that backs out of a system of guarantees of the democratic order under the rule of law that all other public authority in Europe is subject to? And is such a unilateral backing-out of a system of mutual pan-European obligations under the supervision of the European Court of Human Rights really required by the 'constitutional structure' of the Union, as the Court suggests?

It is not unlikely that the Court's resounding nyet, based as it is on a very broad set of widely divergent issues and arguments, is able to rekindle divergent views between member states as well as institutions, so that neither a return to the negotiating table, nor an amendment of the Treaties will be possible. This would be typical for the Union. Its 'constitutional moments' are not determined by revolutionary or catastrophic historical events, but tend to be different. Within the development of EU law, they are changes that form incremental changes and adaptations that, indeed, correlate with political events but seem not to be decisively determined by them. The Opinion on the accession to the ECHR might actually be a negative catalyst.

Accession to the ECHR is 'of constitutional importance' both for the Union and the member states, as the Court held in Opinion 2/94, and could hence not be achieved without a clear constitutional mandate - a mandate that has in the meantime been created as a legally binding commitment. At a moment in time at which Europe threatens to be rifted apart for geo-political reasons, attended by the use of military violence, the constitutional symbolism of complying with that mandate by accession or not complying by non-accession would be politically significant towards the non-EU Convention parties. A non-accession on the basis of the arguments of Opinion 2/13 might be grist for the mill of the enemies of

\footnotetext{
${ }^{30}$ After the text of this Editorial Comment was finalized, the Council Presidency has opted for renegotiating the Accession Agreement to meet the ECJ's objections, although not all member states are equally enthusiastic, see Council document 7977/15, and the Commission's 'technical contribution' on actual amendments to the Accession Agreement in Council document DS 1216/15.
} 
Strasbourg within the EU, and might trigger a further movement away from what seemed to be the pan-European consensus on human rights, democracy and the rule of law since 1989. Letting the momentum pass might turn out to be a more destructive than a constructive constitutional moment. Whether this would occur is a matter of the 'constitution-amending power', which is up to the political organs of the Union and, more essentially, the member states.

$\mathrm{LB} / \mathrm{MC} / \mathrm{JHR}$ 